\title{
Sınıf Öğretmenlerinin İnsan Hakları, Vatandaşlık ve Demokrasi Dersine Yönelik Görüssleri ${ }^{1}$
}

\section{Views of the Classroom Teachers about the Course of Human Rights, Citizenship and Democracy}

\author{
Burak AKÇEŞME² Nuray KURTDEDE-FIDAN ${ }^{3}$
}

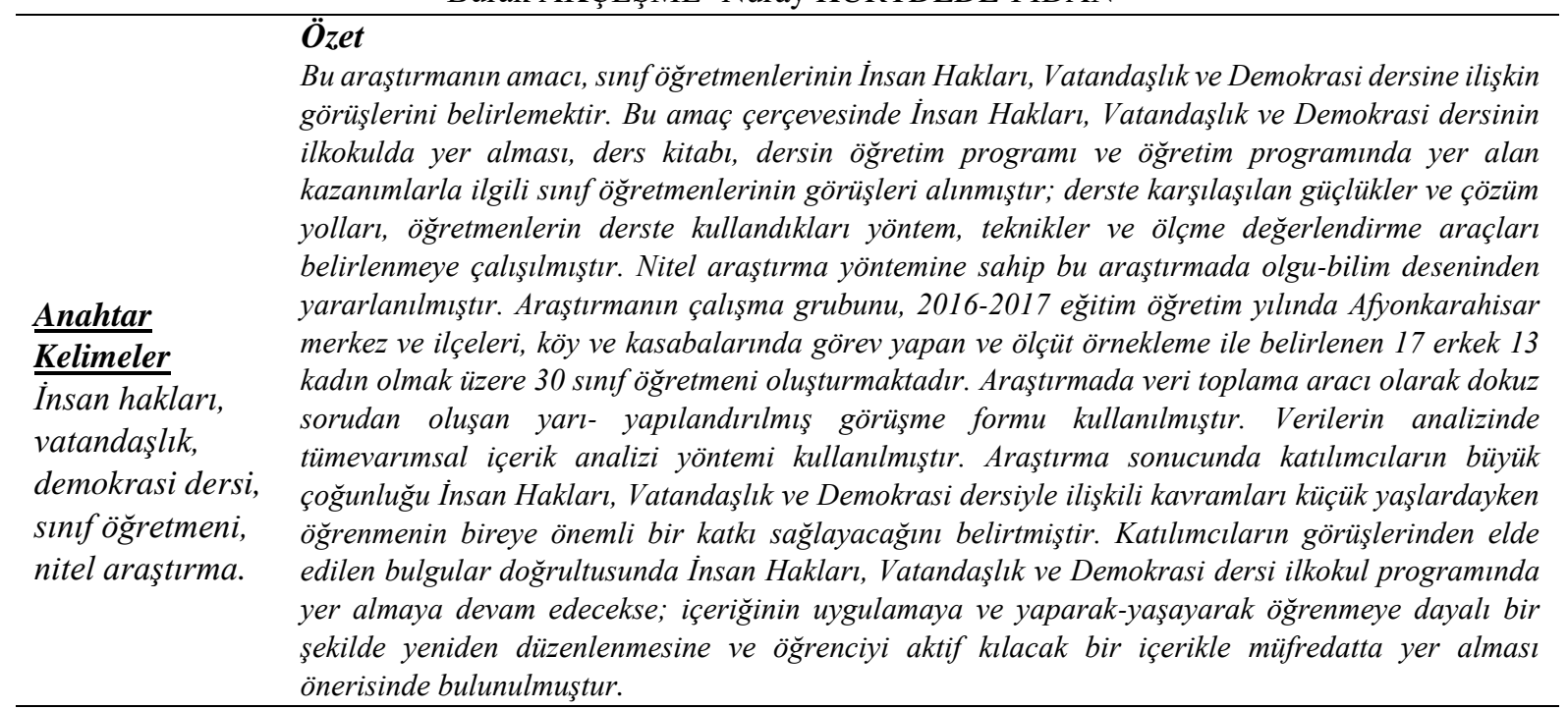

\section{Abstract}

The purpose of this study is to determine the views of the classroom teachers about Human Rights, Citizenship and Democracy. Within the framework of this aim, the opinions of the teachers of the

$\underline{\text { Key Word }}$ classroom were taken regarding the inclusion of the Human Rights, Citizenship and Democracy course in primary school, the textbook, and the achievements in the curriculum and curriculum of the

Human rights, citizenship and democracy course; difficulties and solutions encountered in the course, methods and techniques used in the course, and assessment and evaluation tools were tried to be determined. In this study in which the qualitative research method was used the phenomenology pattern was employed. The participants of the study are thirty classroom teachers (17 male and 13 female) working in the districts, villages and course, classroom teacher, qualitative research method. towns of Afyonkarahisar province in the 2016-2017 academic year. The participants were selected through the criteria sampling. The data of the study were collected using a semi-structured interview form consisting of nine items. The data obtained were analyzed through the inductive content analysis method. As a result of the analyzes, the majority of the participants stated that learning the concepts related to the Human Rights, Citizenship and Democracy course at an early age will make a significant contribution to the individuals. In line with the findings obtained from the views of the participants, it can be argued that if the Human Rights, Citizenship and Democracy course will continue to be included in the primary school education programs, the course content should be reorganized in a way that is based on practice and learning by doing and living, and that its content should make the students active participants of the learning process.

\begin{tabular}{|c|c|}
\hline $\begin{array}{l}\text { Atıf için: } \\
\text { For Citation }\end{array}$ & $\begin{array}{l}\text { Akçeşme, B. \& Kurtdede Fidan, N. (2021). Sınıf öğretmenlerinin insan hakları, vatandaşlik ve } \\
\text { demokrasi dersine yönelik görüşleri. Muğla Sitkı Koçman Üniversitesi Eğitim Fakültesi } \\
\text { [MSKU Journal of Education], 8(1), 147-164. DOI: 10.21666/muefd.779867 }\end{array}$ \\
\hline & Published: 01.05.2021 \\
\hline
\end{tabular}

\footnotetext{
${ }^{1}$ Bu makale, ilk yazartn yüksek lisans tezinden üretilmiştir. Afyon Kocatepe Üniversitesi Bilimsel Araştırma Komisyonu projeleri (16.SOS.BIL.19) tarafindan desteklenmiştir.

${ }^{2}$ MEB, SinıfÖğretmeni, burak_akcesme@hotmail.com ORCID:0000-0002-6566

${ }^{3}$ Afyon Kocatepe Üniversitesi, Eğitim Fakültesi, nkurt@aku.edu.tr ORCID: 0000-0002-2056-1994
} 
Eğitim bireyin toplumsallaşmasını ve çeşitli donanımlar edinmesini sağlayan oldukça karmaşık ve çok boyutlu bir süreçtir. Eğitim toplumdaki istikrarı korumanın yanında bir değişim aracıdır. Tarih boyunca eğitimin esas amacı kültürün tüm nesillere aktarımını sağlamak olmuştur (Güven, 2010). Çocukların topluma hazırlanması eğitimin öngörülen merkezi fonksiyonlarından biridir. İyi ya da kötü, olumlu veya olumsuz, herhangi bir şekilde eğitim insanın bakış açısını, eylemlerini ve ilişkilerini etkiler (Turan ve Yıldırım, 2016). Her konuda eğitilmeye ve bir şeyler öğrenmeye ihtiyaç duyan insanoğlunun, kendisini çok yakından ilgilendiren İnsan Hakları, Vatandaşlık ve Demokrasi hakkında da bilgilendirilmeye ihtiyacı vardır. İnsan hakları, insanın sadece insan olması sebebiyle, insanın değerini ve tüm yönleriyle kişiliğini korumayı ve geliştirmeyi amaçlayan evrensel ilke ve kurallar bütünüdür (Yiğittir, 2014). İnsan hakları ya da kamu özgürlükleri genel olarak, insan onurunu korumay1, maddi ve manevi gelişmesini sağlamayı amaçlayan haklardır (Üste, 2007). Bugün, insan hakları eskiye nispeten daha da önem kazanmış ve sadece iç hukukun değil; uluslararası hukukun da konusu olmuştur (Çiftci, 2015). Uluslararası hukuk ve insan hakları belgeleri vatandaşlığı öncelikle bir hak olarak benimsemiştir. Örneğin; Birleşmiş Milletler Genel Kurulu'nca 10 Aralık 1948'de kabul edilen İnsan Hakları Evrensel Bildirgesi'nde "Herkesin, bir uyrukluğa hakkı vardır." denmektedir (Altunya, 2003). İlk defa 1789 Fransız İhtilali ile siyasi bir anlam kazanan "vatandaş" kelimesi, son iki asırda sözlüklerimize girmiştir. Fransız Millî Meclisi tarafından kabul edilerek 26 Ağustos 1789 tarihinde yayınlanan "İnsan ve Vatandaş/Yurttaş Hakları Beyannamesi" başlıklı belge, vatandaş kelimesini hafizalara yerleştirmiştir (Bakioğlu ve Kurt, 2009). Engle ve Ochoa (1988) vatandaşlı̆̆ı; bir devlet veya millet tarafından bireye atfedilen yasal bir statü olarak tanımlamışlardır (Akt. Merey, Karatekin ve Kuş 2012). Uluslar tarafından bireylere atfedilen vatandaşlık kavramı beraberinde; insan hakları, adalet, eşitlik, özgürlük, devlet kurumlarının işleyişi hakkında bilgi sahibi olma, eleştirel düşünme ve iletişim becerileri gibi yeterliliklere sahip olma imkanı tanımaktadır. Bu özellikler toplumlara demokrasi kavramı ile birlikte girmektedir. Politik bir kavram olan demokrasi bir yönetim, aynı zamanda eşitlik, adalet, hak, özgürlük, sorumluluk, uzlaşma, aklın egemenliği, farklılıklara karşı hoşgörü, insana saygı, dayanışma, paylaşım vb. değerleri barındıran bir yaşam biçimidir (Sadık ve Sarı, 2012). Demokrasi ve insan hakları kavramları birbiriyle doğrudan bağlantılıdır. Bir siyasal rejim olarak demokrasi, insan haklarının gerçekleştirildiği düzeni temsil eder. İnsan hakları ise doktrin olarak demokrasilerin temelini oluşturur (Duman, Yavuz ve Karakaya, 2016). Bireylerin demokratik bir yurttaş olarak yetişmeleri için demokrasinin gerektirdiği bilgi, beceri ve tutumlara sahip olmaları gerekmektedir. Çocukların vatandaşlık, demokrasi ve onlara ilişkin diğer kavramları benimsemeleri ve demokratik tutum ve davranışlarda bulunmaları ancak vatandaşlık ve demokrasi hakkında eğitilmeleriyle mümkün olabilir. $\mathrm{Bu}$ yüzden vatandaşlık bilgisinin ve demokrasinin gelişip yaygınlaşmasında okullarda bu alanda yapılacak faaliyetler büyük öneme sahiptir (Farrell, 1998).

İnsan Hakları, Vatandaşlık ve Demokrasi dersine ilişkin dünyada ve ülkemizde birçok araştırma (Durdi ve Erdamar 2020; Hastürk, 2019; Aslan ve Aybek, 2018; Akdeniz, 2018; Erol 2018; De Araújo ve Afonso, 2018; Tan, Naidu ve Jamil 2018; Karagözoğlu, 2017; Toprak ve Demir, 2017; Oğuz Haçat ve Demir, 2017; Gürel, 2016; Sağlam ve Hayal 2015; Bajaj 2012) yapılmıştır. Durdi ve Erdamar (2020), sosyal bilgiler ve sınıf öğretmenlerinin İnsan Hakları, Vatandaşlık ve Demokrasi dersi programına ilişkin görüşlerini inceledikleri çalışmada; bu dersin öğrenciler için kesinlikle faydalı olduğu, içeriğin daha somut hale getirilmesinin ve daha fazla etkinlik yapılacak şekilde planlamasının verimi arttıracağ sonucuna ulaşmışlardır. Tan, Naidu ve Jamil (2018) araştırmalarında, ahlak eğitimi dersinin ve ders kitaplarının iyi bir vatandaş yetiştirmede etkili, öğrencilerin sorumluluk bilinçlerinin gelişmesine doğrudan katkısı olduğu sonucuna ulaşmıştır. De Araújo ve Afonso (2018), insan hakları eğitiminin hangi dönemde, hangi yöntemler ve araç-gereçlerle yapılacağı konusunda araştırma yapmıştır. Erken çocukluk döneminde verilmesi gereken değerler ile insan hakları eğitimi sayesinde kazandırılacak ilkelerin birleştirilmesi gerektiği hakkında düşünceyi desteklerler. De Araújo ve Afonso (2018)'nun elde ettiği sonuçlara göre insan hakları eğitimi oyunlar, hikayelerden yararlanarak verilmelidir. Aslan ve Aybek (2018), sınıf öğretmenlerinin ilkokul dördüncü sınıf İnsan Hakları, Vatandaşlık ve Demokrasi dersi öğretim programına yönelik görüşleri inceledikleri araştırmada İnsan Hakları dersi sayesinde öğrencilerin kendi hakları ile ilgili bilgi sahibi olacaklarını, topluma karşı sorumluluklarının ve demokrasinin ne olduğunu öğreneceklerini ve bunun yanında da bazı değerleri kazandıklarını belirtmişlerdir. Karagözoğlu (2017), İnsan Hakları, Vatandaşlık ve Demokrasi dersinde gazetelerden yararlanmanın etkisini belirlemek amacıyla yaptı̆̆ çalışmanın sonucunda, ders içeriğinde yer alan insan haklarına ilişkin kazanımların güncel olaylarla ilişkilendirilmesinde gazetelerin verimli bir öğretim aracı 
olarak kullanılabildiği sonucuna ulaşmıştır. Toprak ve Demir (2017), yaptıkları araştırmada dördüncü sınıf öğrencilerinin yaş grubu göz önüne alındığında İnsan Hakları, Vatandaşlık ve Demokrasi dersinin dördüncü sınıfta okutulmasının genel olarak öğrencilere faydalı olacağ 1 sonucuna ulaşmışlardır. Fakat ders kitabı içeriğinin ve İnsan Hakları, Vatandaşlık ve Demokrasi dersi programı kazanımlarının, öğrencilerin bilişsel somut işlemler döneminde olmasından dolayı konu ve kavramlarda sadeleştirmeler yapılarak ve kazanımlar ile ders süresi arasında denge kurulması sağlanarak, derste yaşanan zorlukların üstesinden gelinebileceği yönünde öğretmenlerin çeşitli önerileri olduğu görülmektedir. Gürel (2016), yaptığı araştırmada sosyal bilgiler ve sınıf öğretmenleri vatandaşlık eğitimini iyi, bilgili ve değer sahibi vatandaşların yetiştirilmesi amacıyla verilen eğitim olarak tanımladıkları sonucuna ulaşılmıştır. Katılımcılar, Türkiye'de verilen vatandaşlık eğitiminin kesinlikle gerekli ve daha donanımlı ve yeterlilik düzeyi yüksek öğretmenler tarafından verilmesi gerektiğini belirtmişlerdir.

Birbiriyle bu kadar ortak noktaları, bağlantıları ve ilişkisi olan; hayatın olmazsa olmazı ve mutlaka bilgi sahibi olmamız gereken İnsan Hakları, Vatandaşlık ve Demokrasi kavramları eğitim sistemimiz içinde de sürekli kendisine yer bulmuştur. Gerek Sosyal Bilgiler dersi içerisinde gerekse İnsan Hakları, Vatandaşlık ve Demokrasi dersi başlığı altında ilkokul ve ortaokul programlarında yer almış ve bu kavramlara ait beceriler, yaşantılar eğitim yoluyla kazandırılmaya öğrencilere çalışılmıştır. Daha önce ortaokulda yer alan İnsan Hakları, Vatandaşlık ve Demokrasi dersinin ilkokulda olmasına ve bu dersin kazanımlarına, öğrenme öğretme süreçlerine, derste kullanılan kaynaklara, kullanılan ölçme değerlendirme araçlarına, ayrıca yaşanan sorunlara yönelik sınıf öğretmenlerinin görüşlerinin alındığı araştırmaya ülkemizde çok fazla rastlanmamıştır. Sınıf öğretmenlerinin görüşlerinin alanyazına katkı sağlayacağı öngörülmektedir. Bu bağlamda, bu araştırmada sınıf öğretmenlerinin İnsan Hakları, Vatandaşlık ve Demokrasine ilişkin bakış açılarının ve bu dersteki yaşantılarının ortaya çıkarılması amaçlanmıştır. Bu genel amaç doğrultusunda aşağıdaki sorulara cevap aranmıştır:

1. Sınıf öğretmenlerinin İnsan Hakları, Vatandaşlık ve Demokrasi dersinin ilkokul programında yer alması ile ilgili görüşleri nelerdir?

2. Sınıf öğretmenlerinin İnsan Hakları, Vatandaşlık ve Demokrasi dersinin yararlarına ilişkin görüşleri nelerdir?

3. Sınıf öğretmenlerinin İnsan Hakları, Vatandaşlık ve Demokrasi dersi öğretim programında yer alan kazanımlara ilişkin görüşleri nelerdir?

4. Sınıf öğretmenlerinin İnsan Hakları, Vatandaşlık ve Demokrasi dersinde kullanılan yöntem ve tekniklere ilişkin görüşleri nelerdir?

5. Sınıf öğretmenlerinin İnsan Hakları, Vatandaşlık ve Demokrasi dersinde kullanılan araçgereçlere ilişkin görüşleri nelerdir?

6. Sınıf öğretmenlerini İnsan Hakları, Vatandaşlık ve Demokrasi dersinde kullanılan ölçme değerlendirme araçlarına ilişkin görüşleri nelerdir?

7. Sınıf öğretmenlerinin İnsan Hakları, Vatandaşlık ve Demokrasi dersinde yaşanan güçlüklere ilişkin görüşleri nelerdir?

8. Sınıf öğretmenlerinin İnsan Hakları, Vatandaşlık ve Demokrasi dersinde yaşanan güçlüklerin çözümüne ilişkin görüşleri nelerdir?

9. Sınıf Öğretmenlerinin İnsan Hakları, Vatandaşlık ve Demokrasi dersinin daha etkili olması için önerilere yönelik görüşleri nelerdir?

\section{Yöntem}

\section{Araștırmanın Deseni}

Araştırmanın desenini, nitel araştırma desenlerinden olgu bilim deseni oluşturmaktadır. Olgu bilim araştırma deseninin amacı, bireylerin bir olguya ilişkin yaşantılarını, algılarını ve bunlara yüklediği anlamları ortaya çıkarmaktır (Yıldırım ve Şimşek, 2013). İlkokulda İnsan Hakları, Vatandaşlık ve Demokrasi dersini sınıf öğretmenleri okutmaktadır. Bu dersle ilgili tüm yaşantılar, algılar ve odaklanılan olguların tümünü sınıf öğretmenleri yaşamaktadır. Bu nedenle bu araştırma, sınıf öğretmenlerinin derse yönelik yaşantılarını keşfetmeye yönelik olarak gerçekleştirilen olgu bilimsel bir araştırmadır. Olgu bilim araştırmalarında veri kaynakları; araştırılmak istenen olguyu deneyimleyen bireylerdir (Yıldırım ve Şimşek, 2013). 


\section{Çalışma Grubu}

Araştırmanın çalışma grubunu, 2016-2017 eğitim öğretim yılında Afyonkarahisar merkez ve ilçeleri, köy ve kasabalarında görev yapan ve ölçüt örnekleme ile belirlenen 17 erkek 13 kadın olmak üzere 30 sınıf öğretmeni oluşturmaktadır. Çalışma grubunun belirlenmesinde amaçsal örnekleme yöntemlerinden ölçüt örnekleme kullanılmıştır. Amaçsal örneklemede, araştırma için seçilen durumlar, daha fazla bilgi sağlayacağı ve aydınlatıcı olduğu için seçilir (Christensen, Johnson ve Turner, 2015). Nitel bir analiz için önceden belirlenmiş ölçütlerin karakteristik özelliklerini gösteren veri sistemindeki tüm durumlar derinlemesine incelenmektedir (Patton, 2014). Bu araştırmanın katılımcıları belirlenirken İnsan Hakları, Vatandaşlık ve Demokrasi dersinin dördüncü sınıfta okutuluyor olması sebebiyle dördüncü sınıfı okutan sınıf öğretmenlerinin seçilmesine dikkat edilmiş ve belirlenen ölçüt örnekleme çerçevesinde 30 sinıf öğretmeni de dördüncü sınıfı okutan sınıf öğretmenlerinden seçilmiştir. Araştırmaya katılan sınıf öğretmenlerinin kişisel özellikleri Tablo 1'de sunulmuştur.

Tablo 1

Araştırmaya Katılan Öğretmenlerin Demografik Bilgileri

\begin{tabular}{llll}
\hline Değişken & & Frekans & $\%$ \\
\hline \multirow{2}{*}{ Cinsiyet } & Kadın & 13 & 43.3 \\
& Erkek & 17 & 56.7 \\
& $0-5$ yıl & 3 & 10 \\
Kıdem & $6-10$ yıl & 7 & 23.3 \\
& $11-15$ yıl & 7 & 23.3 \\
& $16-20$ yil & 10 & 33.4 \\
& 21 yil ve üzeri & 3 & 10 \\
\hline
\end{tabular}

Tablo 1'de görüldüğü gibi araştırmaya katılan 30 sınıf öğretmeninden 13'ü kadın, 17'si erkektir. 13 sınıf öğretmeni 16 yıl ve üstünde mesleki kıdeme sahiptir. 11-15 yıl arası ve 6-10 yıl arası görev yapan sınıf öğretmenleri ise yedişer kişiden oluşmakta; 0-5 yıl arası görev yapan sınıf öğretmenlerinin ise 3 kişi olduğu görülmektedir.

\section{Veri Toplama Aracı}

Araştırmada dokuz açık uçlu sorudan ve dört alt sorudan oluşan yarı-yapılandırılmış görüşme formu kullanılmıştır. Bu formu geliştirmek için öncelikle, alanyazın taraması yapılmış, dördüncü sınıf İnsan Hakları, Vatandaşlık ve Demokrasi dersinin programı ve kapsamı gözden geçirilmiş ve tüm boyutlarıyla ele alınmıştır. Daha sonra sekiz soru ve altı alt sorudan oluşan veri toplama aracı oluşturulmuş; uzman görüşü alınarak sorular düzenlenmiş ve dokuz soru dört alt soru olmak üzere veri toplama aracına son şekli verilmiştir.

\section{Araştırmanın Veri Toplama Aracının, Veri Analizlerinin Geçerlik ve Güvenirlik Çalışması}

Görüşme formundaki soruların kapsam geçerliliğini belirlemek amacıyla Sosyal Bilgiler ve eğitim bilimleri alanında çalışmalar yapan dört uzmanın görüşüne başvurulmuştur. Gelen öneriler üzerine gerekli düzenlemeler ve eklemeler yapılmıştır. Görüşme formundaki soruların anlaşılırlığını belirlemek amacıyla iki sınıf öğretmeni ile pilot uygulamalar gerçekleştirilmiştir. Pilot uygulamalar veri toplama aracının geliştirilme sürecinde ve dördüncü sınıf öğretmenleri ile ortalama 15 dakikalık görüşmeler şeklinde gerçekleştirilmiştir. Görüşmeler sonucunda formda yer alan iki sorunun anlaşılmasında problem yaşandığı ve alınan cevapların net olmadığ1 görülmüş ve bu sorular görüşme formundan çıkarılmıştır. Alınan uzman görüşleri ve yapılan pilot uygulamalar sonucunda bazı sorularda daha anlaşılır olması amacıyla cümle kurgularında değişiklikler yapılmıştır. Yapılan düzenlemeler ve eklemeler sonucunda veri toplama aracının amaca hizmet ettiği belirlenip uygulanmaya başlanmıştır.

İlk görüşmelerden sonra "katılımcı kontrolü (membercheck)" uygulaması gerçekleştirilmiştir. Sonuçların geçerliği, kaliteli nitel araştırmanın temel dayanağıdır. Katılımcı kontrolü, sonuçların geçerliğini keşfetmek için bir yöntemdir. Veriler veya sonuçlar, katılımcıların verdiği bilgiler ile doğruluk gösteriyor mu kontrol etmek için katılımcılara geri gönderilir. Bu basit raporlama ile katılımcı vermiş olduğu bilgilerin araştırmada yer verilen yorumlamalarını kabul etmeyebilir (Birt, Scott, Cavers, Campbell ve Walter, 2016). Bir geçerlilik arttırma uygulaması olan katılımcı kontrolü, verilerin toplandığı katılımcılara tekrar ulaşarak, görüşme kayıtları ve o zamana kadar yapılan analizler hakkında 
geri bildirime dayanan bir uygulamadır. Katılımcı kontrolünde amaç araştırmacının katılımcıların söylediği şeyleri kendi ön bilgileri veya önyargıları nedeniyle yanlış anlama ve yorumlama ihtimalini ortadan kaldırmaktır (Merriam, 2013; Maxwell, 2005, akt. Gezer 2016). Katılımcı kontrolü (membercheck), nitel araştırmada önemli bir doğrulama yöntemi olarak belirtilmektedir. Genel olarak, bir araştırmacının katılımcının öznelliğini tespit etmek amacıyla katılımcı kontrolü kullanılır. Bununla birlikte, bazı teorisyenler, nitel araştırmalar için öncelikli bir amaç olarak düşünülmesi gerektiğinden söz etmektedirler (Koelsch, 2013). Araştırmada, toplanan verilerin dökümü ve temel düzeyde verilerin analizi gerçekleştirilmiş̧ir. Anlaşılamayan noktalar not alınmış ve daha sonra katılımcılardan randevu alınarak yapılan dökümler ve gerçekleştirilen analizler katılımcılarla paylaşılmıştır. Sunulan veriler katılımcılar tarafindan kontrol edilerek anlaşılamayan sorular tekrar sorulmuş, yer almasını istemedikleri veriler araştırmadan çıkarılmış ve araştırmacı tarafından anlaşılamayan noktalar tekrar sorularak katılımcılardan cevaplar alınmış ve veriler teyit edilerek katılımcı kontrolü gerçekleştirilmiştir. Ayrıca araştırmada verilerin analizlerinde kodlamalarda ve alt temalarda uyuşum yüzdesi de, Miles ve Hubberman (Miles ve Hubermann, 1994)' 1n, [Görüş birliği / (Görüş birliği + Görüş ayrılığı) x 100] formülü kullanılarak hesaplanmıştır.

\section{Verilerin Toplanma Süreci}

Veriler toplanmadan önce, etik kurul onayı (Afyon Kocatepe Üniversitesi, Bilimsel Araştırma ve Yayın Etik Kurulu'nun değerlendirme kararının tarihi=09.12.2016, Etik değerlendirme belgesi sayı numarası= 2016/137) alınmıştır. Ayrıca Afyonkarahisar İl Milli Eğitim Müdürlüğü’nden gerekli izin alınmıştır. Veriler 20.04.2017 tarihinde başlayıp 08.06.2017 tarihlerinde toplanmıştır. İlkokul dördüncü sınıfta görev yapan 30 sınıf öğretmeni ile gönüllülük esasına dayalı olarak gerçekleştirilen görüşmelerde, katılımcıların izni dâhilinde veriler ses kayıt cihazı ile kaydedilmiştir. Araştırmacı, verileri toplarken bilimsel etik kurallar çerçevesinde hareket etmiştir. Görüşmeler, derslerin bölünmemesi amaciyla katılımcıların dersleri bittikten sonra ve görüşmelerin rahat gerçekleştirilebileceği bir ortamda yapılmıştır.

\section{Verilerin Analizi}

Verilerin analizinde, tümevarımsal içerik analizi kullanılmıştır. İçerik analizinde, araştırmada ulaşılan veriler derin bir çözümlemeye tabi tutularak kavram ve temalara ulaşıllır. İçerik analizi sürecinde veriler kodlanır, belirlenen kodlar tema ve alt temalara göre gruplandırılır (Yıldırım ve Şimşek, 2013). Ses kayıt cihazı ile kaydedilen görüşmeler araştırmacı tarafından worde aktarılmıştır. Yazıya dökülen tüm görüşme verileri iki araştırmacı tarafından ayrı ayrı kodlanmıştır. Birbiriyle ilişkili olan kodlar benzerlik ve farklılıklarına göre sınıflandırılmış ve bu kodlardan hareketle alt temalar belirlenmiştir. Miles ve Huberman (1994)' in önerdiği formüle göre [Görüş birliği /(Görüş birliği + Görüş ayrıllğı) x 100] araştırmacılar arasında \% 92.00 oranında uyuşum bulunmuştur. Bulguların sunumunda elde edilen veriler doğrudan alıntılar ile desteklenmiştir. Doğrudan alıntılarda katılımcıların gizliliğinin sağlanması amaciyla her bir öğretmene kod ad (Mustafa (Ö1), Oğuz ...) verilmiştir.

\section{Bulgular ve Yorum}

Sınıf öğretmenlerinin İnsan Hakları, Vatandaşlık ve Demokrasi dersinin ilkokul programında yer alması ile ilgili görüşleri "İlkokulda Olmalı ve İlkokulda Olmamalı" şeklinde iki alt temada ele alınmıştır. Analizler sonucunda ortaya çıkan alt tema ve kodlar Tablo 2'de verilmiştir. Tablo 2'de görüldüğü gibi sınıf öğretmenlerinin çoğunluğu bu dersin ilkokul programında yer alması gerektiğini belirtirken, bazıları da ilkokulda yer almaması gerektiğini ifade etmiştir. 24 sınıf öğretmeni İnsan Hakları, Vatandaşlık ve Demokrasi dersinin ilkokul programında yer alması gerektiğini belirtmiştir. Öğretmenler, bu dersle öğrencilerin önemli bilgi, beceri ve değerler kazandığını, farklı bakış açılarını öğrendiklerini ve sosyal etkileşimlerinin arttığını ifade etmişlerdir. Bazı sınıf öğretmenleri ise bu dersin içerisindeki kavramların ağır olması ve öğrencilerin anlamakta zorluk çekmesinden ayrıca bu derse ait bilgi, beceri ve değerlere zaten diğer derslerde de yer veriliyor olmasından dolayı ilkokullarda İnsan Hakları, Vatandaşlık ve Demokrasi dersinin olmaması gerektiğini vurgulamıştır. 
Sinıf ögretmenlerinin İnsan Hakları, Vatandaşlık ve Demokrasi Dersinin İlkokul Programında Yer Alması ile İlgili Görüşleri

\begin{tabular}{|c|c|c|c|}
\hline Tema & Alt tema & Kod & $\mathbf{f}$ \\
\hline \multirow{7}{*}{ 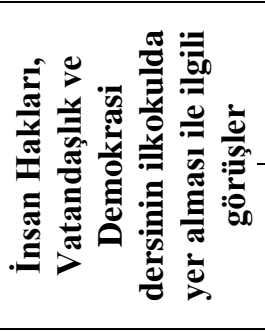 } & & İnsan hakları ile ilgili önemli kavramların öğrenilmesi & 10 \\
\hline & İlkokulda & İnsan hakları ile ilgili önemli değerlerin öğrenilmesi & 7 \\
\hline & & larını öğrenmesi & 3 \\
\hline & & mlerinin artmas 1 & 1 \\
\hline & İlkol & $\begin{array}{l}\text { İlkokuldaki diğer derslerde bu derse ait bilgi, beceri ve değerlerin } \\
\text { kazandırılıyor olması }\end{array}$ & 3 \\
\hline & olmamalı & Öğrencilerin gelişim düzeylerine uygun olmamas1 & 2 \\
\hline & & Kitaptaki kelimelerin ağır ve konuların soyut olması & 2 \\
\hline
\end{tabular}

Öğretmenlerin İnsan Hakları, Vatandaşlık ve Demokrasi dersinin ilkokulda yer alması ile ilgili görüşleri ile ilgili doğrudan alıntılar şu şekildedir: Mustafa öğretmen (Ö1) "Insan Hakları, Vatandaşlık ve Demokrasi dersinin ilkokullarda yer alması geleceğimiz açısından, çocuklarımız açısından; gerçek anlamda demokrasinin ne olduğunun, bundan daha öte insan haklarının ne olduğunun öğretilmesi açısından çok önemlidir." şeklinde; Oğuz öğretmen (Ö2) ise "Çocukların demokrasi, empati gibi birçok kavramları öğrenmesi açısından olumlu olduğunu düşünüyorum. Mesela çocuklar aralarındaki sorunları şiddet yoluyla çözme taraftarı ama biz bu dersle bunların çözüm olmayacağını gayet güzel işliyoruz. İnsan Hakları, Vatandaşlık ve Demokrasi dersinin müfredata konulması bu bakımdan güzel bir olay." görüşleriyle belirtmiştir.

Elde edilen verilerden hareketle İnsan Hakları, Vatandaşlık ve Demokrasi dersinin ilkokul programında yer alması genel anlamda olumlu karşılanmaktadır. Bu derse ait insan hakları, vatandaşlık, demokrasi, eşitlik vb. kavramların; sevgi, saygı, adalet, sorumluluk vb. gibi değerlerin öğrenilmesi açısından, öğrencilerin sosyalleşmesi ve farklı bakış açıları geliştirmesi yönlerinden dersin katkısı olduğu ifade edilmektedir. Dersin ilkokul düzeyine uygun olmadığını ifade eden sınıf öğretmenleri ise öğrencilerin düzeyinden, bu derste verilen kavramların diğer dersler içerisinde zaten veriliyor olmasından ve dersin sunuluş şekli olarak kitaptaki kelimelerin öğrencilerin gelişiminin üstünde ve konuların soyut olmasından dolayı İnsan Hakları, Vatandaşlık ve Demokrasi dersinin ilkokul programında yer alması ile ilgili olumsuz görüş belirtmişlerdir.

Sınıf öğretmenlerinin İnsan Hakları, Vatandaşlık ve Demokrasi dersinin ilkokul öğrencilerine yararlarına ilişkin görüşleri "Bilgi, Beceri, Tutum ve Değerler Açısından" üç alt temada ele alınmıştır. Analizler sonucunda ortaya çıkan alt tema ve kodlar Tablo 3 'te sunulmuştur ve ardından bu alt tema ve kodlara ilişkin doğrudan alıntılara ve yorumlara yer verilmiştir.

Tablo 3

Sinı öğretmenlerinin İnsan Hakları, Vatandașlık ve Demokrasi Dersinin Yararlarına İlișkin Görüssleri

\begin{tabular}{|c|c|c|c|}
\hline Tema & Alt tema & Kod & f \\
\hline \multirow{7}{*}{ 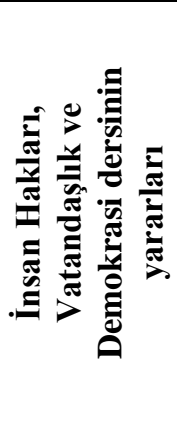 } & \multirow{3}{*}{$\begin{array}{c}\text { Bilgi } \\
\text { açısından }\end{array}$} & Bilgi sahibi olma & 7 \\
\hline & & Hakların önemli olduğunu anlama & 6 \\
\hline & & Bilgi, beceri ve değerlerin erken yaşlarda kazandırılması & 3 \\
\hline & $\begin{array}{c}\text { Beceri } \\
\text { açısından }\end{array}$ & $\begin{array}{l}\text { Hakların neden korunmas1 gerektiği bilincine varma ve ona } \\
\text { göre davranma }\end{array}$ & 2 \\
\hline & \multirow{3}{*}{$\begin{array}{l}\text { Tutum ve } \\
\text { Değerler } \\
\text { açısından }\end{array}$} & $\begin{array}{l}\text { Öğrenilenlerin bilgi, beceri ve değerleri davranışlarına } \\
\text { yansıtma }\end{array}$ & 6 \\
\hline & & Yaşadığı toplumun değerlerini anlama ve ona göre davranma & 2 \\
\hline & & $\begin{array}{l}\text { Farkındalık, duyarlılık, bilinç, düşünce, tutum ve davranı̧̧ } \\
\text { kazandırma }\end{array}$ & . \\
\hline
\end{tabular}

Tablo 3’te görüldüğü gibi sınıf öğretmenlerinin neredeyse tamamı İnsan Hakları, Vatandaşlık ve Demokrasi dersinin ilkokul öğrencileri için yararlı olduğunu belirtmiştir. Bu ders ile öğrencilerin insan hakları ile ilgili birçok bilgi kazandığı, İnsan Hakları, Vatandaşlık ve Demokrasi ile ilgili hakların neden korunması gerektiği bilincine varma ve ona göre davranma olarak beceriler kazandıkları ve değerler kazandıkları vurgulanmıștır. Katılımcılar İnsan Hakları, Vatandaşlık ve Demokrasi dersinin insan hakları ve demokrasi hakkında bilgi sahibi olmayı sağladığı, bu derse ait kavramların küçük yaşlarda öğretilmesinin kolay olması açısından yararlı bulduklarını belirtmiştir.

Öğretmenlerin İnsan Hakları, Vatandaşlık ve Demokrasinin dersinin yararları ile ilgili görüşlerinden doğrudan alıntılar şu şekildedir: Tayfun öğretmen (Ö3) "Tabi ki yararlıdır. Çocuk küçük yaşlardan bu 
yana haklarının ne olduğunu bilecek tabi bunun yanında sorumluluklarını da ögrenmiş olacak... Biz çocuklara insan haklarl verirken sorumluluklarının da önemli olduğunu, bunların da verilmesi gerektiği kanaatindeyiz; veriyoruz da. Tabi ilkokul çağlarında hatta daha öncelerden verilmesi lazım. İlkokula gitmeyen bir çocuğun bile evde bir yaşama hakkının, bir oyun hakkının, beslenme hakkının olabildiğini bilmesi lazım...", olarak; Elif öğretmen (Ö4) "Kesinlikle yararlı olduğunu düşünüyorum. Ders hikâyelerle aktarllyyor, oradaki her kavramı algılayamıyor olabilirler ama teması, içeriği hoşlarına gidiyor." şeklinde ifade etmiştir.

İnsan Hakları, Vatandaşlık ve Demokrasi dersinde öğrenilenlerin bilgi, beceri ve değerleri davranışlarına yansıtma açısından yararlı olduğunu; Betül öğretmen (Ö20) "Yararlıdır, özellikle dördüncü sınıfta yaşlarına uygun olarak gelişsimleri açısından karşılaştıkları bir olayda haksızlık yapıldl, hile yapıldı sürekli bu düşünceleri ve yorumları var onları yenmek açısından önemlidir" diyerek; Büşra öğretmen (Ö21) "Yararlıdır. Küçük yaşta hak, sorumluluk, özgürlük gibi kavramları tanıyorlar ve bunu günlük yaşamda uygulayabiliyorlar." şeklinde ifade etmiştir.

Sınıf öğretmenleri; İnsan Hakları, Vatandaşlık ve Demokrasi dersinin ilkokul öğrencileri için yararlı olduğunu düşünmektedir. Bilgi, beceri ve tutum ve değerler açısından dersin yararlarını belirten katılımcılar; derse ait kavramların farkına varma, bunları önemseme ve hayatlarına uyarlama anlamında önemli katkı sağladığını ifade etmiştir.

Sınıf öğretmenlerinin İnsan Hakları, Vatandaşlık ve Demokrasi dersi öğretim programında yer alan kazanımlara ilişkin görüşleri üç alt temada ele alınmıştır. Analizler sonucunda ortaya çıkan alt tema ve kodlar Tablo 4 'te sunulmuş ve ardından doğrudan alıntılara ve yorumlara yer verilmiştir.

Tablo 4

Sınıf Öğretmenlerinin Insan Hakları, Vatandaşlık ve Demokrasi Dersi Öğretim Programında Yer Alan Kazanımlara İlişkin Görüşleri

\begin{tabular}{|c|c|c|c|}
\hline Tema & Alt Tema & Kod & $\mathbf{f}$ \\
\hline \multirow{4}{*}{ 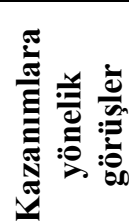 } & Olumlu Görüşler & Kazanımlar yeterli ve seviyelerine uygun & 19 \\
\hline & Olumsuz Görüşler & Kazanımlar öğrencilerin seviyelerine uygun değil & 5 \\
\hline & & Kazanımlar bilgi düzeyinde & 1 \\
\hline & Öneriler & $\begin{array}{l}\text { Kazanımlar sadeleştirilmeli } \\
\text { Kazanımların sayısı azaltılmalı }\end{array}$ & $\begin{array}{l}5 \\
2\end{array}$ \\
\hline
\end{tabular}

Tablo 4'te görüldüğü gibi katılımcıların büyük çoğunluğu "programda yer alan kazanımları yeterli bulduğunu ifade etmiş̧tir. Bazı öğretmenler ise kazanımların sadeleştirilmesi gerektiğini, öğrencilerin seviyelerine uygun olmadığını belirtmiştir. Kazanımlara yönelik önerilerde ise kazanımların sadeleştirilmesi ve sayısının azaltılması gerektiğine yönelik önerilerde bulunmuşlardır.

Dersin kazanımlarının sayısına ve öğrenci seviyesine uygunluğu açısından olumlu görüşlerini belirten öğretmenlerden yapılan doğrudan alıntılar şu şekildedir: Ahmet öğretmen (Ö5) "Yeterli olduğunu düşünüyorum açıkçası. Çok fazla derin değil, çocukların anlayacă̆ı tarzda zaten hikâyeleştirilmiş bir şekilde anlatıldığı için çocuklara, çocukların anlayacă̆ı tarzda, anlayacağı düzeyde kazanımlar olduğunu düşünüyorum.”, Veli öğretmen (Ö6) “Bizim ünite planlarımızdaki kazanımlar kitabımızda bulunan hikâyeler ve hikâyelerin sonunda bulunan soru-cevaplar birbirini bütünlüyor. Bütünlediği için hem ögrencilerimiz için faydalı olmuş oluyor hem de programın dördüncü sınıfa uygun olduğunu gösteriyor." şeklinde ifade etmiştir.

Kazanımlarla ilgili olumsuz görüşlerini belirten öğretmenlerden yapılan doğrudan alıntılar şu şekildedir: Esra öğretmen (Ö7) "Kazanımlar çok fazla, azaltılması gerekiyor. Kazanımlar daha çok ortaokul düzeyi için uygun olduğunu düşünüyorum. O yüzden basitleştirilmeli diye düşünüyorum.”, Kadir öğretmen (Ö8) "Bu derste geçen kazanımlar soyut ve çok fazla yoğun onun için sadeleştirilmeli diye düşünüyorum. " ifadelerinde bulunmuştur.

Sınıf öğretmenlerinin İnsan Hakları, Vatandaşlık ve Demokrasi dersinde kullandıkları yöntem ve teknikler, iki alt temada ele alınmıştır. Bu veriler Tablo 5'te sunulmuş ve ardından doğrudan alıntılara ve yorumlara yer verilmiştir.

Tablo 5

Sinıf Öğretmenlerinin İnsan Hakları, Vatandaşlık ve Demokrasi Dersinde Kullandıkları Yöntem ve Teknikler

\begin{tabular}{llll}
\hline Tema & Alt tema & Kod & f \\
\hline
\end{tabular}




\begin{tabular}{cclc}
\hline & $\begin{array}{c}\text { Geleneksel yöntem ve } \\
\text { teknikler }\end{array}$ & Soru-cevap & 19 \\
& & Onlatım & 15 \\
& & Beyin firtınas & 9 \\
& & Drama & 2 \\
\hline & Yapılandırmacı & Ornek olay & 20 \\
& Güncel yaşamla bağlantı kurdurma & 12 \\
& & Tartı̧ma & 2 \\
& Gezi-gözlem-inceleme & 1 \\
\hline
\end{tabular}

Tablo 5'te görüldüğü gibi, sınıf öğretmenleri İnsan Hakları, Vatandaşlık ve Demokrasi dersinde daha çok soru-cevap, anlatım, okuma ve beyin fırtınası yöntem ve tekniklerini kullandıklarını belirtmiştir. Ayrıca, öğretmenler drama, örnek olay, güncel yaşamla ilişki kurma, tartışma ve gezi-gözlem-inceleme yöntemlerini kullandıklarını belirtmiştir. Öğretmenlerin hem geleneksel hem de yapılandırmacı uygulamalara yer verdikleri söylenebilir.

İnsan Hakları, Vatandaşlık ve Demokrasi dersinde geleneksel yöntem ve tekniklerden yararlandığına yönelik öğretmenlerin görüşlerinden doğrudan alıntılar şu şekildedir: Ahmet öğretmen (Ö5) "Dediğim gibi hani 1.sınıftan beri yaptı̆̆ımız, ögretmenin kitaptaki hikâyeyi okumast, ögrrencilerin dinlemesi ve bunun sonucunda soru-cevap şeklinde dersin işlenmesi.",

Mevlüt öğretmen (Ö9) "Genellikle bu dersi işlerken Türkçe dersine çok benziyor yani elimizdeki kaynaklar ve imkânlar doğrultusunda okuma, karşıllıkl konuşma, soru-cevap şeklinde geçiyor daha çok bunu yapabiliyoruz bunun dlşına çıkamıyoruz. ";

Elif öğretmen (Ö4) "Biz okuyoruz önce normalde sonra o hikâyeyle ilgili sorular yöneltiyorum sorucevap genellikle o şekilde işliyoruz. Hikâye okuyoruz ve üzerinde konuşuyoruz açıkçası."

İnsan Hakları, Vatandaşlık ve Demokrasi dersinde dramadan yararlandığını ifade eden öğretmenlerin görüşlerinden doğrudan alıntı şu şekildedir: Mustafa öğretmen (Ö1) “ Bu derste genellikle dramadan yararlanıyorum. Ögrenciler anlatılmak istenilenleri daha iyi anllyor ve dersi daha çok seviyorlar

Sınıf öğretmenlerinin İnsan Hakları, Vatandaşlık ve Demokrasi dersinde yararlandıkları araç gereçlere ilişkin görüşleri iki alt temada ele alınmıştır. Analizler sonucunda ortaya çıkan alt tema ve kodlar Tablo 6 'da sunulmuş ve ardından doğrudan alıntılara ve yorumlara yer verilmiştir.

Tablo 6'da görüldüğü gibi, görüşme yapılan sınıf öğretmenlerinin tamamı İnsan Hakları, Vatandaşlık ve Demokrasi ders kitabından yararlandığını belirtmiştir. Ayrıca katılımcılar, ders kitabının dışında öğrencilere film, çizgi film ve animasyon, reklam ve kamu spotu izletme amaciyla bilgisayar ve projeksiyondan yararlandıklarını belirtmiştir. Ayrıca on katılımcı akıllı tahta, on bir sınıf öğretmeni bu derste ders kitabının dışında herhangi bir teknolojik araç gereç kullanmadığını belirtmiştir.

Tablo 6

Sinıf Öğretmenlerinin İnsan Hakları, Vatandaşlık ve Demokrasi Dersinde Yararlandıkları AraçGereçlere İlişkin Görüşleri

\begin{tabular}{|c|c|c|c|}
\hline Tema & Alt tema & Kod & $\mathbf{f}$ \\
\hline \multirow{9}{*}{ 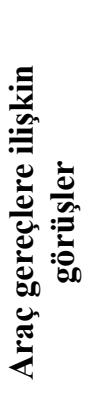 } & \multirow{8}{*}{$\begin{array}{c}\text { Araç gereçlerden } \\
\text { yararlanma }\end{array}$} & Ders Kitab1 & 30 \\
\hline & & Bilgisayar ve projeksiyon & 19 \\
\hline & & Film izletme & 8 \\
\hline & & Animasyon çizgi filmden yararlanma & 5 \\
\hline & & Reklamlardan yararlanma & 2 \\
\hline & & Kamu spotlarından yararlanma & 2 \\
\hline & & Görsellerden yararlanma & 2 \\
\hline & & Ak1llı tahta & 10 \\
\hline & $\begin{array}{l}\text { Araç gereçlerden } \\
\text { yararlanmama }\end{array}$ & $\begin{array}{l}\text { İnsan Hakları, Vatandaşlık ve Demokrasi dersinde teknolojik araç } \\
\text { gereçten yararlanmama }\end{array}$ & 11 \\
\hline
\end{tabular}

Katılımcıların bu derste birçok araç gereçten yararlandığına yönelik görüşlerinden doğrudan alıntılar şu şekildedir: Mustafa öğretmen (Ö1) "Okullarda kullanılabilecek tüm teknolojik araçlardan yararlaniyorum. Akill tahtadan yararlaniyorum var sinıfimda aktif, projeksiyondan yararlaniyoruz var aktif. Bilgisayarımız var aktif.", Beyza öğretmen (Ö10) ise "Akıllı tahtadan, videolardan, projeksiyon, bilgisayar; EBA'dan yararlaniyorum. Konularla ilgili uygun kisa filmler izletebiliyorum. O şekilde." Ramazan öğretmen (Ö11) "Genellikle projeksiyon, şu anda akill tahta okulumuza henüz gelmedi. 
Bilgisayardan faydalanıyoruz. Topladı̆̆ımız bilgileri USB'ye atıyoruz, paylaşmamız gerekirse çocuklarla projeksiyon vasitasıyla yansitıp o şekilde teknolojik aletlerden faydalanıyoruz.".

İnsan Hakları, Vatandaşlık ve Demokrasi dersinde herhangi bir araç-gereçten yararlanmama nedenini ise; Ahmet öğretmen (Ö5)" Elimizde devletin dă̆ıtmış olduğu kitabın haricinde bir materyal olmadiğından dolayı görselleştirme şansımızın az olduğunu düşünüyorum açıkçası. Bundan dolayı hani ĕger devletimiz, MEB, TTK ders kitaplarının yanında ĕger ayrı bir $C D$, interaktif bir $C D$ gönderebilirlerse görselleş̧tirebileceğimizi, bununla beraber işte bilgisayar, projeksiyon gibi araç ve gereçlerinin kullanılmasının sağlanabileceğini düşünüyorum.” Büşra öğretmen (Ö21) "Teknolojik araçları çok kullanma ihtiyacımız olmuyor. Görsel anlamda merak edilen bir şey olursa ancak o zaman bilgisayar kullanabiliyoruz." şeklinde ifade etmiştir.

Sınıf öğretmenlerinin İnsan Hakları, Vatandaşlık ve Demokrasi dersinde kullandıkları ölçme değerlendirme araçlarına ilişkin alt tema ve kodlar Tablo 7'de sunulmuştur. Tablo 7'de görüldügüü gibi sınıf öğretmenlerinin İnsan Hakları, Vatandaşlık ve Demokrasi dersinde kullandıkları ölçme değerlendirme teknikleri "geleneksel ölçme değerlendirme teknikleri" ve "alternatif ölçme değerlendirme teknikleri” olmak üzere iki alt temada ele alınmıştır. Sınıf öğretmenlerinin neredeyse tamamı geleneksel ölçme değerlendirme tekniklerinden yararlandıklarını belirtmiştir. İki sınıf öğretmeni ise bu derse ait bir ölçme değerlendirme yapmadığını ve ders içi performansa bağlı değerlendirme yaptıklarını belirtmiştir. Sınıf öğretmenleri İnsan Hakları, Vatandaşlık ve Demokrasi dersinde geleneksel ölçme değerlendirme tekniklerini kullandıkları görülmektedir.

Tablo 7

Sinıf Öğretmenlerinin İnsan Hakları, Vatandaşlık ve Demokrasi Dersinde Kullandıkları Ölçme Değerlendirme Araçlarına İlişkin Görüşler

\begin{tabular}{|c|c|c|c|}
\hline Tema & Alt Tema & Kod & $\mathbf{f}$ \\
\hline \multirow{6}{*}{ 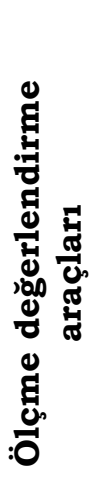 } & \multirow{5}{*}{$\begin{array}{c}\text { Geleneksel } \\
\text { ölçme } \\
\text { değerlendirme } \\
\text { araçları }\end{array}$} & Açık uçlu sorularla sınav & 28 \\
\hline & & Doğru-yanlış soruları & 28 \\
\hline & & Test & 28 \\
\hline & & Eşleştirme & 28 \\
\hline & & Boşluk doldurma & 28 \\
\hline & $\begin{array}{c}\text { Alternatif } \\
\text { ölçme } \\
\text { değerlendirme } \\
\text { araçları }\end{array}$ & $\begin{array}{l}\text { Öz değerlendirme, öğrenci dosyas } 1 \text { ve } \\
\text { öğrenci performans değerlendirme }\end{array}$ & 2 \\
\hline
\end{tabular}

Genellikle geleneksel ölçme araçlarını kullandığını ifade eden katılımcılardan doğrudan alıntılar şu şekildedir:

Ayşe öğretmen (Ö12) “Biz ikişer yazılı yapıyoruz her dönem bu derste. Yazılıları da çok zor muhakkak bir şey bilin cinsinden hazırlamıyorum. Daha çok çocuğun tahmin edebileceği kendi yaşantısına uygun sorular hazırlamaya çalışıyorum. Yani okuduğu zaman öyle bir olayı ya da durumu kendisi de kafasında canlandırsın ona göre nasıl olmalıdır diye düşünmesi lazım.",

Filiz öğretmen (Ö22) "Klasik yazıl y yapıyoruz. Doğru-yanlış, çoktan seçmeli sorular, boşluk doldurma, eşleştirme ve klasik sorular sorabiliyoruz bu şekilde."

Tuğçe öğretmen (Ö13) "Ölçme değerlendirme normal sinav yapmak zorunda olduğumuz için sinava yönelik soru-cevap veriyorum. Genellikle dediğim gibi bunlart ilk önce sinıfta işliyoruz soru-cevap halinde daha sonra o konulardan o sorduğum sorulardan sınav yapıyorum. Test, açık uçlu soru ve boşluk doldurma şeklinde hepsini kullanıyoruz sinavlarda. Sözlü notu vereceksek onu da dersteki katılımından ve bu drama çalışmalarındaki kendini ifade etme becerilerine baklyorum."

İnsan Hakları, Vatandaşlık ve Demokrasi dersinde herhangi bir ölçme değerlendirme yapmayan öğretmenlerden Ahmet öğretmen Ö5 "Yani, ölçme değerlendirme araçlarını kullanmadık çünkü şöyle söyleyeyim: ilk geçen sene uygulandiğı için bu ders ben açıkçası şöyle düşündüm: hani çocuklara bu kavramları ezberletmek yerine anlattı̆̆ımı hikâyelerle çocuğun yaparak yaşayarak öğrenmesini sağlamayı amaçladık. Yani hikâyelerden ders çıkarmasını, görsellerden yeni bilgiler ögrenmesini 
sağlayarak, dersin biraz daha eğlenceli hale getirilmesini sağladık. Not konusunda da çocukları çok fazla sıkmadık." şeklinde görüşünü belirtmiştir.

Sınıf öğretmenlerinin İnsan Hakları, Vatandaşlık ve Demokrasi dersinde yaşanan güçlüklere ve bu güçlüklere yönelik çözüm önerilerine ilişkin görüşleri iki temada toplanmıştır. Bu tema, alt tema ve kodlara ilişkin bulgular Tablo 8'de sunulmuşstur.

Tablo 8'de görüldüğü gibi İnsan Hakları, Vatandaşlık ve Demokrasi dersinde 24 sınıf öğretmeni en çok dersten kaynaklı sorunlar yaşadığını ve dersten kaynaklı sorunların ise; ders içeriğinin soyut olmasından, ders kitabının içeriğinden ve ders saatinin az olmasından kaynaklandığını belirtmiştir. 14 sınıf öğretmeni ise öğrenci kaynaklı sorunlar yaşadıklarını, bu sorunların öğrencinin hazırbulunuşluluğundan, kavramları anlamakta zorlanmalarından ve öğrenilenlerin kalıcı olmamasından kaynaklandığını belirtmiştir. Yedi sınıf öğretmeni derse dair güçlüklerin sınıf öğretmeninden kaynaklandığından bahsetmiş ve bu güçlüklerin genellikle öğretmenin anlatım yöntemini kullanma ve dersi işlerken zamanı yetiştirememeden olduğu belirtmiştir. 10 sınıf öğretmeni bu derste yaşanan güçlüklerin veli kaynaklı olduğunu; derste öğretilenler-öğrenilenler ile ailede öğretilen-öğrenilenlerin çatışması, veliler ile sınıf öğretmenlerinin iş birliği eksikliği ve velilerin bilinçli olmamasından kaynaklandığını belirtmiştir. Son olarak bir sınıf öğretmeni de yaşanan güçlüklerin fiziksel ortam kaynaklı olduğunu ve yeterli araç-gereç olmamasının fiziksel yetersizliğe neden olduğunu ifade etmiştir.

Tablo 8

Sinıf Öğretmenlerinin İnsan Hakları, Vatandaşlık ve Demokrasi Dersinde Yaşanan Güçlüklere ve Çözüm Önerilerine Illişkin Görüşleri

\begin{tabular}{|c|c|c|c|}
\hline Tema & Alt tema & Kod & $\mathbf{f}$ \\
\hline \multirow{11}{*}{ 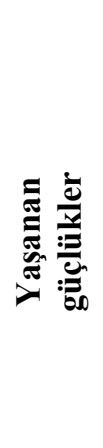 } & \multirow{3}{*}{ Ders kaynaklı } & Ders içeriğinin soyut olması & 14 \\
\hline & & Ders kitabının içeriği & 6 \\
\hline & & Ders saatinin az olmas 1 & 4 \\
\hline & \multirow{3}{*}{ Öğrenci kaynaklı } & Öğrencilerin hazırbulunuşluğunun yetersizliği & 7 \\
\hline & & Öğrencilerin kavramları anlamada zorlanması & 5 \\
\hline & & Öğrenilenlerin kalıcı olmaması & 2 \\
\hline & \multirow[b]{2}{*}{ Öğretmen kaynaklı } & Genellikle anlatım yönteminin kullanılması & 5 \\
\hline & & Zamanı verimli kullanamama & 2 \\
\hline & \multirow{3}{*}{ Veli kaynaklı } & Derste öğrenilenler ile ailede yaşananların çatışması & 7 \\
\hline & & Veliler ile işbirliği eksikliği & 2 \\
\hline & & Velilerin bilinçli olmaması & 1 \\
\hline \multirow{5}{*}{ 窇 } & Fiziksel ortam kaynaklı & Drama etkinliklerinin yapılacağı alan olmaması & 1 \\
\hline & \multirow{3}{*}{ Sınıf içi uygulamalar } & $\begin{array}{l}\text { Çocukların günlük yaşamlarından örnekler verme ve ilişki } \\
\text { kurdurmaya çalışma }\end{array}$ & 11 \\
\hline & & Dramadan yararlanma & 7 \\
\hline & & Tartışma yönteminden yararlanma & 5 \\
\hline & Kaynaklar & $\begin{array}{l}\text { Kitaptaki metinleri kısaltma ve özetleme } \\
\text { Farklı kaynaklardan yararlanma }\end{array}$ & 3 \\
\hline
\end{tabular}

İnsan Hakları, Vatandaşlık ve Demokrasi dersinde yaşanan güçlüklerin dersten kaynaklı olduğunu; Oğuz öğretmen (Ö2) “......Bu derste kavramların birçoğu soyut kavramlar olduğu için çocuklar bunu söylemede, anlamada ve anlatmada zorluk çekiyor." diyerek belirtmiştir.

Öğrenciden kaynaklanan sorun yaşadığını Zuhal öğretmen (Ö14) "Çocukların hazırbulunuşluk seviyelerinin düşük olduğunu düşünüyorum. Çocuk hak hukuk kavramlarını biliyor ama işin içine yasa anayasa falan girince çocuk bunları algılamakta zorlanıyor, karıştırıyor. " şeklinde açıklamıştır.

Öğretmen kaynaklı sorunları Ali öğretmen (Ö15) "Bu derste yaşanan güçlüklerin kaynağı başta öğretmen. Insan haklarl, demokrasi kavramların özümseyecek, yaptı̆̆ uygulamalarla da çocuğa örnek olacak.", diye ifade ederken;

Kadir öğretmen (Ö8) “Başta ilk önce İnsan Hakları dersinde öğretmenlerin yetersiz olmasından kaynaklanabilir” şeklinde açıklamıştır.

Veli kaynaklı sorunu Sema öğretmen (Ö16) "Eğitime ailenin katılmamast, eğitim-öğretimi ailenin desteklememesi olarak görüyorum.” diyerek açıklamıştır. 
Fiziksel ortam kaynaklı sorunu Süleyman öğretmen (Ö17) “... fiziki alan, materyal bulma bunlarla ilgili sıkıntılar var. Örneğin bir canlandırma gerçekleştireceğiz; sınıfımızın kü̧̈ük olması da bazen buna engel olan durumlar arasında bulunabiliyor." şeklinde dile getirmiştir.

Sınıf öğretmenlerinin çoğunluğu, kitapta verilen metinleri çocukların hayatlarına uyarlayarak çocukların anlamalarını kolaylaştırmaya yönelik etkinlikler yaptıklarını belirtmiştir. Sınıf öğretmenleri İnsan Hakları, Vatandaşlık ve Demokrasi dersinde karşılaşılan güçlükleri çözmek için drama, tartışma ve güncel olaylardan yararlandıklarını belirterek derste yapılandırmacı uygulamaların daha etkili olduğunu savunmuştur. Bu şekilde güçlükleri ortadan kaldırmaya çalıştıklarını belirtmiştir.

İnsan Hakları, Vatandaşlık ve Demokrasi dersinde yaşanan güçlüklere yönelik çözüm önerileri ile ilgili katılımcılardan doğrudan alıntılar şu şekildedir:

Güncel olaylardan yararlanarak çözdüğünü Süleyman öğretmen (Ö17) “Bu konuları canlandırmaya dökerek çocukların hem dersi anlamasını hem de eğlenerek zevk almalarını sağladık." ifade etmiş̧ir.

Ek kaynaklar kullanarak ve dramadan yararlanarak çözdüğünü Tuğçe öğretmen (Ö13) "Günlük hayatla iliş̧kilendirmeye çalışım her zaman anlayabilmeleri açısından. Anlatılan konudaki ağır ise o konu ile ilgili günlük hayatta yaşadığımız bir örneği vermeye çalıştım. Bunların drama şeklinde canlandırarak çocukların anlamasını sağllyorum. ” diyerek, görüşlerini açıklamıştır.

Yine güncel olayla ilişkilendirip ve çocuğa görelik ilkesine göre çözdüğünü ifade eden Selma öğretmen (Ö18) "Basite indirgeyerek kendi yaşantılarına uydurarak onların da yaşayabileceği bazı olaylarla benzeştirerek o şekilde çözmeye çalıştık." diyerek belirtmiştir.

Sınıf öğretmenlerinin İnsan Hakları, Vatandaşlık ve Demokrasi dersinin daha etkili olması için önerilere yönelik görüşlerine ait veriler, beş alt temada ele alınmıştır. Analizler sonucunda ortaya çıkan alt tema ve kodlar Tablo 9'da sunulmuş ve ardından doğrudan alıntılara ve yorumlara yer verilmiştir.

Tablo 9

Sinıf Öğretmenlerinin İnsan Hakları, Vatandaşlık ve Demokrasi Dersinin Daha Etkili Olması için Önerilere Yönelik Görüşleri

\begin{tabular}{|c|c|c|c|}
\hline Tema & Alt tema & Kod & $\mathbf{f}$ \\
\hline \multirow{13}{*}{ 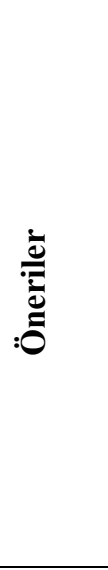 } & \multirow{5}{*}{$\begin{array}{l}\text { Öğretmenlere yönelik } \\
\text { öneriler }\end{array}$} & Öğrenci merkezli etkinlikler düzenlemeli & 8 \\
\hline & & Gezi gözlem inceleme yöntemi kullanmalı & 2 \\
\hline & & Sınıfa uzman kişiler davet etmeli & 2 \\
\hline & & Derse planlı bir şekilde girmeli & 2 \\
\hline & & Programi incelemeli & 2 \\
\hline & \multirow{3}{*}{$\begin{array}{l}\text { İHVD dersine yönelik } \\
\text { öneriler }\end{array}$} & İHVD dersi ayrı bir ders olarak olmamalı & 5 \\
\hline & & Sosyal bilgiler dersinde ayrı bir ünite olarak verilmeli & 2 \\
\hline & & Hayat bilgisi dersinde verilmeli & 1 \\
\hline & \multirow{2}{*}{$\begin{array}{l}\text { Ders kitabına yönelik } \\
\text { öneriler }\end{array}$} & Güncel yaşamdan konulara yer vermeli & 5 \\
\hline & & Hikâyelerdeki kavramlar öğrencilerin gelișim özelliğine uygun olmalı & 5 \\
\hline & \multirow{2}{*}{$\begin{array}{l}\text { Velilere yönelik } \\
\text { öneriler }\end{array}$} & Veliler ilgili olmalı & 5 \\
\hline & & Okulda öğrenilenlere yönelik veliler destek vermeli & 2 \\
\hline & $\begin{array}{l}\text { Fiziksel olanaklara } \\
\text { yönelik öneriler }\end{array}$ & $\begin{array}{l}\text { Çeşitli araç gereçler sağlanmalı (Filmler, animasyonlar, kamu spotları, } \\
\text { dergiler vb.) }\end{array}$ & 1 \\
\hline
\end{tabular}

Tablo 9'da görüldüğü gibi sınıf öğretmenlerinin İnsan Hakları, Vatandaşlık ve Demokrasi dersinin daha etkili olması için önerilere yönelik görüşleri beş alt temada toplanmıştır. Sınıf öğretmenlerinin üçte birine yakını verilmesi gereken kazanımların sadeleştirilmesi gerektiğini ve öğrencilerin dikkatini çeken içeriğe yer verilerek zenginleştirilebileceğini ifade etmiştir. Az sayıda sınıf öğretmeni İnsan Hakları, Vatandaşlık ve Demokrasi dersinin ayrı ders olarak okutulmaması gerektiğini düşünse de; bu düşüncede olmayan sınıf öğretmenleri ise bu dersin işlenme sürecinde öğrenci merkezli uygulamalara yer verilmesi gerektiğini, gezi-gözlem-inceleme yönteminin kullanılmasını, uzman kişilerin çağrılmasını, güncel yaşamdan konulara yer verilmesi gerektiğini, derse karşı velilerin ilgili olmasının gerektiği ve ders işleme sürecinde kullanılmak üzere çeşitli araç gereçler temin edilmesi gerektiğini belirtmişlerdir.

$\mathrm{Bu}$ derste alan uzmanından yararlanılmasının etkili olacağını Mustafa öğretmen (Ö1) " $B u$ derste ögrenilenler ile ögrrencilerin birebir temas halinde olması gerekir yani yaparak yaşayarak ögrenmeleri gerekir. Illçede bir insan hakları komisyonu var adliye binasında. İsterim ki ögrrencilerle birlikte (psikolojisini ne kadar etkiler etkilemez ayrı bir konu) bu konuya bakan (insan hakları konusuna) savcı 
beyle çocuklarımı konuşturmak isterim. Ceza savcısıyla ceza hâkimiyle senede en az bir ders saatlik, çocukların anlayabileceği dilden çocuklara anlatmasını isterim. ..." diyerek ifade etmiştir.

Kitapla ilgili önerisini; Aykut öğretmen (Ö23) “... kitapta görseller çok az, anlatılanlar yazılanlar şekil itibariyle çocuğun anlayacă̆l şekilde değil; baya üzerinde. Görseller arttırllabilir bir de konular basitleştirilebilir.", şeklinde ifade ederken; Kitaptaki metinlerin çok uzun olduğunu, konuların ağır olduğunu Esra öğretmen (Ö7) "Metinler kisaltılabilir. Somutlaştırılabilir ve soyut konular çıkartılabilir." diyerek, Mevlüt öğretmen ise (Ö9) "Bu konuda kitaplardaki içerik yetersizdir bunlar gelişstirilmelidir ..." şeklinde dile getirmiştir.

Sınıf öğretmenlerinin İnsan Hakları, Vatandaşlık ve Demokrasi dersiyle ilgili hizmet içi eğitime yönelik görüşleri alındığında katılımcıların on yedisi hizmet içi eğitime ihtiyacı olduğunu ifade etmiştir. Katılımcılar, derste kullanılacak yeni yöntem ve tekniklere ilişkin, dersteki bilgi, beceri ve değerlerin kazandırılmasına yönelik eğitime ihtiyacı olduğunu vurgulamıştır:

Burhan öğretmen (Ö19)“Mutlaka ek bilgi lazım oluyor bize, bilgi olarak sinırlı olduğumuzu ve daha fazla materyale ihtiyacımız olduğunu düşünüyorum...

Tuğçe öğretmen (Ö13) ise "Açıkçası insan hakları ile ilgili bir eğitim alınabilir. Mesela biz okuldan mezun olurken böyle bir ders yoktu ve biz bunun ĕgitimini almadık. Beden eğitimi, resim, müzik vs. bunlarının hepsinin eğitimini aldık ama bunun eğitimini almadık. Bu müfredatı nasıl işlememiz gerektiği ile ilgili bir ĕgitim alınabilir."

\section{Sonuç, Tartışma ve Öneriler}

Araştırmada ilkokulda okutulan İnsan Hakları, Vatandaşlık ve Demokrasi dersine yönelik sınıf öğretmenlerinin görüşleri belirlenmeye çalışılmıştır. Araştırmaya katılan sınıf öğretmenlerinin çoğunluğu İnsan Hakları, Vatandaşlık ve Demokrasi dersi sayesinde insan hakları, vatandaşlık, hak, hukuk, adalet, eşitlik, uzlaşı, demokrasi vb. kavramların daha küçük yaşlardayken öğrenmenin bireylere önemli katkılar sağlayacağını vurgulamıştır. Ayrıca ilerleyen dönemde bu kavramları benimseme ve hayata uygulamada kolaylıklar sağlayacağı konusunda görüşler belirtmişlerdir. Araştırma sonucunda sınıf öğretmenlerinin İnsan Hakları, Vatandaşlık ve Demokrasi dersinin ilkokulda yer almasının uygun olduğunu vurguladıkları görülmüştür. Eğitimin ve eğitimcilerin, özellikle de çocuklarla ilgili olarak, bir sosyal sorumluluğu vardır. Birincisi, onların kendi haklarının ve başkalarının haklarının farkında olmalarını sağlamak için insan haklarının savunulması ve eğitiminin verilmesidir. İkinci olarak, çocuklarda hem gerekli bilginin kazanılması, becerinin geliştirilmesi hem de çocukluktan itibaren çocukların demokratik becerilere sahip bir insan olarak yetiştirilmesi için okul, hakların eğitiminde ayrıcalıklı bir alan olarak kabul edilmelidir (De Araújo ve Afonso, 2018). İnsan Hakları, Vatandaşlık ve Demokrasi dersinin dördüncü sınıfta okutulması genel olarak öğrencilere faydalı olacaktır (Toprak ve Demir, 2017). Araştırmacılar tarafından yapılan çalışmalarda da ilkokullarda İnsan Hakları, Vatandaşlık ve Demokrasi dersinin verilmesinin önemli olduğu sonuçlarına ulaşılmıştır. Er, Ünal ve Özmen (2013) sekizinci sınıf Vatandaşlık ve Demokrasi Eğitimi dersinin dördüncü sınıfa alınmasına ilişkin görüşler üzerine bir araştırma adlı çalışmasında katılımcılar, vatandaşlık ve demokrasi kavramlarının ve bilincinin erken yaşlarda kazanıldığını ve dersin ilkokulda olmasının uygun olduğunu vurgulamıştır. Durdi ve Erdamar, (2020)' 1 araştırmasında ise, öğretmenler bu dersin içeriğinin soyut olduğunu, konularının ilkokul seviyesine uygun olmadığını, ders saatinin artırılmasını ve dersin sosyal bilgiler öğretmenleri tarafindan yürütülmesi gerektiğini belirtmiş̧ir. Hastürk (2019) ve Erol (2019) araştırmalarında öğretmenler bu derse ait kavramların dördüncü sınıf seviyesinde soyut düşünme becerisi yeterince gelişmemiş öğrenciler için uygun olmayacağını, bu nedenle dersin ortaokul düzeyinde ayrı bir ders olması gerektiğini düşündükleri sonucuna ulaşılmıştır. Yapılan diğer araştırmalarda ise (Balbağ, Bayır ve Ersoy 2017; Oğuz Haçat ve Demir, 2017; Toprak ve Demir, 2017; Sağlam ve Hayal, 2015; Ülger ve Yel 2013; Aydeniz 2010) dersin ilkokulda olmasının uygun olduğu yönündedir.

Sınıf öğretmenleri İnsan Hakları, Vatandaşlık ve Demokrasi dersi öğretim programında yer alan kazanımlarla ilgili olarak; kazanımların sayı olarak yeterli olduğunu ama içeriğinde birtakım düzenlemeler ile iyileştirmeler yapılabileceği fikrinde birleşmektedir. Öğretmenler, kazanımların öğrencilerin seviyelerine uygun şekilde ve bilgi düzeyinden beceri, tutum ve değer düzeyinde davranışlar kazandırmaya yönelik olarak yeniden düzenlenmesi gerektiğini belirtmiştir. Aslan ve Aybek (2018), Purcu (2019), Toprak ve Demir (2017)' in araştırmasında da dördüncü sınıf İnsan Hakları, Vatandaşlık ve Demokrasi dersinin kazanımlarının öğrencilerin seviyelerinin üzerinde olduğu sonucuna 
ulaşılmışıır. Toprak ve Demir (2017) araştırmalarında, kazanım sayısı ve kapsamının fazla olmasına rağmen bu ders için ayırılan ders süresinin yetersiz olduğunu vurgulamıştır. Kazanım sayısının fazla olmasının aynı zamanda ders kitabına yansımasından dolayı dersin işlenmesini olumsuz etkilediği sonucuna ulaşmışlardır.

Sınıf öğretmenleri tarafından İnsan Hakları, Vatandaşlık ve Demokrasi dersinin faydalarına ilişkin olarak; insan hakları ile ilgili kavram ve değerlerin öğrenilmesi, öğrencilerin farklı bakış açıları edinmeleri ve sosyal etkileşimlerinin artması gibi katkılar sağlayacağı belirtilmiştir. Lohrenscheit (2002), tarafından yapılan çalışmada, insan hakları eğitimi aracılığıyla demokrasi, adalet, özgürlük, dayanışma, barış, onur, haklar ve sorumluluk kavramlarına ilişkin bir anlayış ve duyarlılık geliştirildiği belirtilmiştir (Akt. Aslan ve Aybek, 2018). Gürel (2016), sınıf ve sosyal bilgiler öğretmenlerinin ilkokul dördüncü sınıf İnsan Hakları, Vatandaşlık ve Demokrasi dersine yönelik görüşlerini belirledikleri çalışmada öğretmenler; bireylerin bilinçli, uyumlu, hayata hazır, demokratik değerlere sahip, saygıll, çözüm odaklı, karşılaştığı problemleri çözebilen, sorumlu ve haklarını bilen yurttaş olarak yetiştirilmelerinin ancak vatandaşlık eğitimi ile mümkün olabileceğini ifade etmiştir. Oğuz Haçat ve Demir, (2017) araştırmaları sonucunda, öğretmenler bu ders ile öğrencilerin hak, özgürlük ve sorumluluk yönünden çocuk olmanın ayrıcalıklarını keşfetmekte ve değerler hakkında bilgiler edinmektedir diye belirtmiştir.

Sınıf öğretmenleri İnsan Hakları, Vatandaşlık ve Demokrasi dersinde bazen geleneksel yöntem ve tekniklerini, çoğunlukla ise yapılandırmacı uygulamaları kullandıklarını belirtmiştir. Bu dersin sadece bilgi boyutunda öğrenilenlerle kalmaması, öğrenilen bilgilerin beceri, tutum ve davranışa dönüştürülmesi için ders sürecinde öğrencilerin aktif kılınması gerekmektedir. İnsan hakları eğitiminde ilkeler anlatım yoluyla değil; oyunlar, hikâyeler, etkinlikler ve uygulamalar ile kazandırılmalıdır (De Araújo ve Afonso, 2018). Patel (2012) insan hakları eğitiminin sadece müfredata bağlı olarak yürütülmesinin kalıcı bir öğrenme sağlamada yetersiz kalacağını, bunun yerine öğrenciyi aktif kılan uygulamalara dayalı etkinliklerle öğretme sürecinin yürütülmesinin daha faydalı olacağını ifade etmektedir.

Sınıf öğretmenleri İnsan Hakları, Vatandaşlık ve Demokrasi dersinde, çoğunlukla ders kitabını kullanmaktadırlar. Ders kitabı dışında farklı araç-gereçler de kullanmaktadırlar. Fakat bu araç-gereçleri az kullanmaktadırlar. Bu araç-gereçlerin başında internet, bilgisayar ve akıllı tahta gelmektedir. Sınıf öğretmenleri bilgisayar ve akıllı tahtayı konuyla ilgili görsellerden, kamu spotlarından, videolardan ve filmlerden yararlanmak amacıyla kullandıklarını belirtmiştir. Öğrenciler, internetten İnsan Hakları, Vatandaşlık ve Demokrasi konularında proje çalışmalarına katılabilirler. Böylece, öğrenciler düşüncelerini dile getirme özgürlügünü kullanıp karar alma süreçlerine katıldıkları için katılım becerilerini geliştirmiş olur. Karagözoğlu (2017), yaptığı çalışmada İnsan Hakları, Vatandaşlık ve Demokrasi dersi öğretim sürecinde güncel gazete haberlerinden yararlanmanın öğrenciler üzerinde etkili ve öğrenmeyi kolaylaştırdığı sonucuna ulaşmıştır. Topkaya (2014), İnsan Hakları, Vatandaşlık ve Demokrasi dersinde eğitici çizgi roman gibi kaynaklardan yararlanmanın öğrencilerin başarılarını, derse yönelik tutumlarını ve demokratik algılarını olumlu yönde etkilediği sonucuna ulaşmıştır.

Sınıf öğretmenleri İnsan Hakları, Vatandaşlık ve Demokrasi dersinde ölçme değerlendirmede geleneksel değerlendirme araçlarını kullandıklarını belirtmiş̧tir. Açık uçlu, doğru-yanlış, test, eşleştirme ve boşluk doldurma soruları ile öğrencilerin bilgi düzeyinde yoklandığı sınavlar gerçekleştirilmektedir. Balbağ, Bayır ve Ersoy (2017)' un yaptıkları araştırmada da, öğretmenlerin öğrencileri geleneksel değerlendirme teknikleri ile değerlendirdiği sonucuna ulaşılmıştır. Geleneksel ölçme değerlendirme teknikleri demokrasi ve vatandaşlık dersi değerlerinin ne derecede kazanıldığını belirlemede yetersiz kalabilir ve sadece sonuç odaklı değerlendirme yapılabilir. Bunun yanında süreci de değerlendirme olanağı sunan alternatif ölçme değerlendirme teknikleri de muhakkak kullanılmalıdır.

Sınıf öğretmenlerinden elde edilen verilere göre İnsan Hakları, Vatandaşlık ve Demokrasi dersinde; ders kaynaklı, öğrenci kaynaklı, öğretmen kaynaklı, veli kaynaklı ve fiziksel ortam kaynaklı sorunlar yaşandığı belirlenmiştir. Sınıf öğretmenleri tarafından ders içeriğinin soyut olması, öğrencilerin hazırbulunuşluğunun yetersizliği, genellikle anlatım yönteminin tercih edilmesi, derste öğrenilenler ile çevrede ve ailede öğrenilenlerin çatışması ve yeterli araç-gereç bulunmaması bir sorun olarak belirtilmiştir. Gürel (2016) tarafından yapılan araştırmanın da desteklediği şekilde; öğretmen yetersizliği, derste kullanılacak araç-gereç eksikliğinden kaynaklanan ve ders kaynaklı sorunlar olarak ifade edilmiştir. Ayrıca ders kaynaklı olan sorunlardan olan sayısal olarak ders kitabı eksikliği, konuların öğrencilerin bulunduğu dönem özelliklerinden farklı olarak soyut olması, haftalık ders saatinin azlığı ve 
öğrenilen bilginin sadece bilgi olarak kalması ve uygulamaya aktarılamaması önemli sorunlar arasında gösterilmektedir. Katılımcılar, yaşanan sorunların çözümünde farklı materyaller kullanılması, dersin mümkün olduğunca somutlaştırılarak işlenmesi ve öğrencilerin derse katılımının sağlanmasını ön plana çıkarmaktadır. Gündüz (2018) yapmış olduğu çalışmada öğrencilerle yapılacak ders, her türlü etkinlik ve proje çalışmalarında araç-gereç temini noktasında katkıda bulunulursa çok daha verimli ve güzel sonuçların ortaya çıkacağı sonucuna ulaşmıştır. İnsan hakları ve demokrasi eğitiminde, bilgi boyutu ne kadar önemli olsa da tutum ve davranış boyutu daha önceliklidir. Çünkü bilmek yaşantıya aktarıldığı sürece anlamlı olacaktır. Bundan dolayı, öğretim yöntemlerini belirlerken, tutum ve beceri kazandırmaya uygun yöntemlerin seçilmesine dikkat edilmelidir (Yeşil, 2004). Durdi ve Erdamar, (2020)'ın araştırmasında da, öğretmenler derse ayrılan sürenin artırılması, öğrenci merkezli etkinliklerin yer alması gibi bazı öneriler getirmiştir. Sınıf öğretmenleri İnsan Hakları, Vatandaşlık ve Demokrasi dersinde yaşanan güçlüklere, çocukların günlük yaşamlarından örnekler vererek ve bu örnekleri derste yer alan konularla ilişkilendirerek ve yapılandırmacı uygulamalardan yararlanarak çözüm bulduklarını belirtmiştir. Balbağ, Bayır ve Ersoy (2017) yaptıkları çalışmada, öğretmenler ve öğrenciler dersin etkili olmasına ilişkin ortak olarak günlük yaşamla ilişkilendirmeyi ve görsel materyaller kullanmayı önermiştir.

Katılımcılar, İnsan Hakları, Vatandaşlık ve Demokrasi dersinin daha etkili olması için dersin içeriğine, dersi okutan sınıf öğretmenlerine yönelik uyarı ve önerilerde bulunmuştur. Ders içeriğinin ilkokul öğrencisinin anlayabileceği şekilde sadeleştirilmesi gerektiğini; sınıf öğretmenlerinin derste öğrenci merkezli etkinlikler düzenlemesi gerektiğini dile getirmişlerdir. Ünveren ve Gündüz (2020) yapmış oldukları çalışmalarında değer eğitimi yaparken veya önemli şahsiyetlerin hayatlarından ya da söylemlerinden örnekler sunarken çocukların içinde bulundukları gelişim dönemlerinin bilinmesi gerektiğini belirtmiştir. Buradan hareketle de çocuklara uygun yaşantılar sağlanarak ve etkinlikler düzenlenerek derslerin işlenmesinin daha verimli olacağ önerisinde bulunmuşlardır. Aslan ve Aybek (2018)' in, yaptıkları çalışmada katılımcılar öğrenme öğretme sürecinde öğrenci merkezli etkinlikler düzenlediklerini belirtmiştir. Bu bağlamda; gezi-gözlem-inceleme de yapılabileceğini belirtmişlerdir. Demokrasinin ne olduğunun teorik olarak aktarılmasından daha çok demokratik tutum ve becerilerin kazandırılmasına önem verilmesi ve yaparak yaşayarak öğrenme ortamlarının oluşturulması; öğrencilerin demokrasiyi içselleştirmeleri için okul ortamında demokrasinin yaşatılması gerekir (Sadık ve Sar1, 2012).

Katılımcılar İnsan Hakları, Vatandaşlık ve Demokrasi dersi için hizmet içi eğitimler verilmesini ve ders esnasında kullanılmak üzere bir kılavuz kitabın bulunması gerektiğini vurgulamıştır. Araştırmanın bu bulgusu Kaymakçı (2015), tarafından yapılan araştırma ile örtüşmektedir. Aynı araştırmada, katılımcının çoğunluğu ilkokul dördüncü sınıfta okutulacak İnsan Hakları, Vatandaşlık ve Demokrasi dersi için hizmet-içi eğitime ihtiyaç duyduklarını belirtmiştir.

Araştırmadan elde edilen bulgular ve tartışmalardan hareketle aşağıdaki önerilere yer verilmiştir.

1. İnsan Hakları, Vatandaşlık ve Demokrasi dersi ile ilgili araştırma yapmak isteyen araştırmacılara yönelik; araştırma esnasında gözleme dayalı veri toplanmasına da yer verilebilir. $\mathrm{Bu}$ şekilde verilerin zenginleştirilmesi, fotoğraflanması ve sınıfta gerçekleştirilen uygulamaların bizzat görülmesi açısından faydalı olabilir.

2. İnsan Hakları, Vatandaşlık ve Demokrasi dersinin ilkokulda planlamasını gerçekleştiren kurumlara yönelik olarak; ders içeriğinin ve kazanımlarının öğrencilerin hazırbulunuşluluğu göz önüne bulundurularak daha somut bir şekilde hazırlanması daha faydalı olacaktır. Ders kitabının eğlenceli ve faydalı etkinliklerle donatılması, öğretim programında yer alan kazanımların sayısının azaltılması ya da ilkokul İnsan Hakları, Vatandaşılı ve Demokrasi dersinin ders saatinin arttırılması dersin daha verimli şekilde işlenmesini sağlayacaktır.

3. Dersin işlenmesi esnasında kullanılmak amaciyla $\mathrm{CD}$, kamu spotu, reklam vb. araç-gereçlerin hazırlanması ve dönem başında okullara gönderilmesi önerilebilir.

4. İlkokul dördüncü sınıfta İnsan Hakları, Vatandaşlık ve Demokrasi dersini okutan sınıf öğretmenlerine yönelik; ders işlenirken yaparak-yaşayarak öğrenme ortamı sunularak öğrencilerin derse aktif katılımı sağlanmalıdır. 


\section{Kaynakça}

Akdeniz, B. (2018). İlkokul 4. sınıf insan hakları, yurttaşlık ve demokrasi dersi öğretim programının öğretmen görüşlerine göre değerlendirilmesi (Kastamonu Örneği). (Yayınlanmamış yüksek lisans tezi). Kastamonu Üniversitesi Sosyal Bilimler Enstitüsü, Kastamonu.

Altunya, N. (2003). Vatandaşlık bilgisi. Nobel Yayın Dağıtım.

Aslan, S., \& Aybek, B. (2018). Sınıf öğretmenlerinin ilkokul 4. sınıf insan hakları, vatandaşlık ve demokrasi dersi öğretim programına yönelik görüşlerinin incelenmesi. Gazi Üniversitesi Ĕgitim Fakültesi Dergisi, 38(1), 233-262

Aydeniz, D. (2010). İlköğretim 4. 5. sınıf sosyal bilgiler dersinin insan hakları ve demokrasi eğitimindeki işlevselliği. (Yüksek lisans tezi), Sakarya Üniversitesi Sosyal Bilimler Enstitüsü, Sakarya.

Bajaj, M. (2012). From "time pass" to transformative force: School based human rights education in Tamil Nadu, India. International Journal of Educational Development, 32(1),72-80.

Bakioğlu, A. ve Kurt T. (2009). Öğretmenlerin demokrasi vatandaşlık ve vatanseverlik algılarının nitel olarak incelenmesi. Marmara Üniversitesi Atatürk Eğitim Fakültesi Eğitim Bilimleri Dergisi, 29, 19-39.

Balbağ, N. L., Gürdoğan Bayır, Ö., \& Ersoy, A. F. (2017). İnsan hakları, yurttaşlık ve demokrasi dersini öğretmenler ve ögrenciler nasıl alg1lıyor? Sakarya University Journal of Education, 7(1), 223241.

Birt, L., Scott, S., Cavers, D., Campbell, C., \& Walter, F. (2016). Memberchecking: A tool to enhance trust worthiness or merely a nod to validation?. Qualitative Health Research, 26(13), 18021811.

Christensen, L. B., Johnson, B., \& Turner, L. A. (2015). Araştırma yöntemleri: desen ve analiz. (2.Baskı). (A. Aypay, Çev.) Anı Yayıncılık.

Çiftci, A. (2015). Vatandaşlık bilgisi (Demokrasi ve İnsan Hakları). Ankara: Gündüz Yayıncılık.

De Araújo, A. S. S., \& Afonso, M. L. M. (2018). Human rights education in early childhood education: formation of subjects of rights. Revista Eletrônica de Educação, 12(1), 46-60.

Duman, T., Karakaya, N., \& Yavuz, N. (2016). Insan haklart ve demokrasi vatandaşlık bilgisi. Pegem Yayıncilik.

Durdi, M., \& Erdamar, G. (2020). Sosyal bilgiler ve sınıf öğretmenlerinin 4. sınıf insan hakları, yurttaşlık ve demokrasi dersi öğretim programına ilişkin görüşleri. JRES, 7(1), 193-218.

Er, H., Ünal, F., \& Özmen, C. (2013). 8. sınıf vatandaşlık ve demokrasi eğitimi dersinin 4. sınıfa alınmasına ilişskin görüşler üzerine bir araştırma. The Journal of Academic Social Science Studies, 6(8), 179-196.

Erol H. (2018). Vatandaşlık ve insan hakları eğitimi dersinin ortaokul öğretim programından çıkarılmasına ilişkin bir değerlendirme. Diyalektolog Ulusal Sosyal Bilimler Dergisi, 17, 51-67.

Farrell, J. P. (1998). Democracy and education: Who gets to speak and who is listened to?. Curriculum Inquiry, 28(1), 1-7.

Gezer, U. (2016). Sosyal bilgiler dersinde kariyer bilinci geliştirme: öğretmen görüş ve uygulamaları. (Yayımlanmamış Yüksek Lisans Tezi). Anadolu Üniversitesi, Eğitim Bilimleri Enstitüsü. Eskişehir

Gündüz, M. (2018). Öğrencilerin hayat bilgisi dersinde yaptıkları projelerin sorumluluk duygusuna katkısı hakkındaki görüşlerin değerlendirilmesi, Elektronik Sosyal Bilimler Dergisi, 17(68), 1374-1385. 
Gürel, D. (2016). Sınıf ve sosyal bilgiler öğretmenlerinin ilkokul 4. sınıf insan hakları, vatandaşlık ve demokrasi dersine yönelik görüşlerinin karşılıklı olarak incelenmesi. Ahi Evran Üniversitesi Kırşehir Eğitim Fakültesi Dergisi, (KEFAD), (17)3, 641-660.

Güven, S. (2010). İlköğretim birinci kademede vatandaşlık eğitimi üzerine bir durum çalışması. (Doktora Tezi). Gazi Üniversitesi Eğitim Bilimleri Enstitüsü, Ankara.

Hastürk, E. (2019). Sosyal bilgiler öğretimi uzmanları ve öğretmenlerinin gözünden insan hakları, yurttaşlık ve demokrasi dersine bakmak: Bu dersi kim vermeli? (Yayımlanmamış Yüksek lisans tezi), Marmara Üniversitesi, Eğitim Bilimleri Enstitüsü, İstanbul.

Karagözoğlu, N. (2017). İnsan hakları eğitiminde gazetelerden yararlanma. Kırşehir Eğitim Fakültesi Dergisi, 18(3), 64-79.

Kaymakçı, S. (2015). İlkokul öğretmenlerinin gözünden demokrasi ve insan hakları eğitimi. Öztürk, M., Saydam, A., Palancı, M. ve Kırpık, C. (Ed.). Demokrasi, Yurttaşlık ve Insan Hakları eğitimi ilkokul 4. sinıf için etkinlik örnekleri içinde (1.Baskı) (s.19-49). Orka matbaa.

Koelsch, L. E. (2013). Reconceptualizing the membercheck interview. International Journal of Qualitative Methods, 12(1), 168-179.

Merey, Z., Karatekin, K., \& Kuş, Z. (2012). İlköğretimde Vatandaşlık eğitimi: Karşılaştırmalı bir çalışma. Gazi Üniversitesi Gazi Eğitim Fakültesi Dergisi, 32(3), 795-821.

Miles, M. B., \& Huberman, M. A. (1994). Qualitative data analysis: An expanded source book. London: Sage Publication.

Oğuz Haçat, S., \& Demir, F. (2017). İlkokul dördüncü sınıf öğrencilerinin insan hakları, yurttaşlık ve demokrasi dersine ilişkin görüşleri. Türkiye Bilimsel Araştırmalar Dergisi, 2(1), 1-17.

Patel, B. M. (2012). Human rights and education. Indian Streams Research Journal, 2(11).

Patton, M. Q. (2014). Nitel araştırma ve değerlendirme yöntemleri. (3. Bask1) (M. Bütün ve S.B. Demir, Çev). Pegem Akademi.

Purcu, S.S. (2019). İnsan hakları yurttaşlık ve demokrasi dersi öğretim programının ögelerine ilişkin öğretmen görüşleri ile öz-yeterlik inançları arasındaki ilişkinin incelenmesi. (Yayımlanmamış yüksek lisans tezi). Marmara Üniversitesi Eğitim Bilimleri Enstitüsü, İstanbul

Sadık, F., \& Sarı, M. (2012). Çocuk ve demokrasi: İlköğretim öğrencilerinin demokrasi algılarının metaforlar aracılığılla incelenmesi. Uluslararası Cumhuriyet Eğitim Dergisi. 1, 48-62.

Sağlam, H. İ., \& Hayal, M. A. (2015). Sınıf öğretmenlerinin "insan hakları, yurttaşlık ve demokrasi" dersinin ilkokul 4. Sınıfta yer almasına ilişkin görüşleri. Abant İzzet Baysal Üniversitesi Eğitim Fakültesi Dergisi, 15(1), 207-217.

Tan, B. P., Naidu, N. B. M., \& Jamil, Z. (2018). Moral values and good citizens in a multi-ethnic society: A content analysis of moral education text books in Malaysia. The Journal of Social Studies Research, 42(2), 119-134.

Topkaya, Y. (2014). Vatandaşlık ve demokrasi eğitimi dersinde eğitici çizgi roman kullanımının bilişsel ve duyuşsal öğrenmelere etkisi. (Yayımlanmamış doktora tezi). Atatürk Üniversitesi. Erzurum.

Toprak, E., \& Demir, S. B. (2017). İlkokul 4. sınıf “İnsan Hakları, Vatandaşlık Ve Demokrasi” dersinde yaşanan sorunların sınıf öğretmenleri tarafindan değerlendirilmesi. Abant İzzet Baysal Üniversitesi Eğitim Fakültesi Dergisi, 17(4), 2160-2179.

Turan, R., \& Yıldırım, T. (2016). Sosyal bilgilerin temelleri. Anı Yayınc1lık.

Ülger, M., \& Yel, S. (2013). Ara disiplin alanı olarak insan hakları ve vatandaşlık eğitimi ile ilgili ilköğretim öğretmenlerinin yeterlik algıları. Uluslararası Avrasya Sosyal Bilimler Dergisi, 4(10), 19-32. 
Ünveren, D., \& Gündüz, M. (2020). Türkçe dersinde değer eğitimi bağlamında kullanılan Mevlana’nın sözlerini ilkokul öğrencilerinin anlama düzeyi, International Journal of Language Academy, $8(1), 1-15$.

Üste, R. B. (2007). İnsan hakları eğitimi ve ilköğretimdeki önemi. Ege Akademik Bakış Dergisi, 1, 295 310.

Yeşil, R. (2004). İnsan hakları ve demokrasi eğitiminde yöntem. Gazi Üniversitesi Eğitim Fakültesi Dergisi, 5(1), 35-41.

Yıldırım, A., \& Şimşek, H. (2013). Sosyal bilimlerde nitel araştırma yöntemleri. Seçkin Yayıncılık.

Yiğittir, S. (2014). Temel insan hak ve özgürlükleri. İ. Acun, B. Tarman ve E. Dinç. (Ed.) Internet destekli etkin insan hakları demokrasi ve vatandaşlık eğitimi içinde (2. Baskı) (s.2-13). Pegem Akademi.

\section{Extended Abstract}

\section{Introduction}

Individuals must have the necessary knowledge, skills and attitudes in regard to democracy in order to be a democratic citizen. The adoption of citizenship, democracy and other concepts related to them, and democratic attitudes and behaviors can only be acquired by children if they receive formal education about citizenship and democracy. Therefore, the activities to be carried out in this field at schools are of great importance in the development and spread of citizenship knowledge and democracy. Children gain knowledge, skills and value regarding these concepts through the Human Rights, Citizenship and Democracy course and the Social Studies course. Children may acquire the learning outcomes of these studies at an early age. The aim of this study is to determine the views of classroom teachers on the Human Rights, Citizenship and Democracy course. Based on this framework, the views of the classroom teachers were obtained about the inclusion of the Human Rights, Citizenship and Democracy course at primary schools, the textbook, the educational program of the course and the learning outcomes stated in the program, the difficulties encountered in the courses as well as solutions, the methods, techniques and measurement-assessment tools used by the teachers in the courses.

\section{Method}

In this study in which the qualitative research method was used the phenomenology pattern was employed. The participants of the study are thirty classroom teachers (17 male and 13 female) working in the districts, villages and towns of Afyonkarahisar province in the 2016-2017 academic year. The participants were selected through the criteria sampling. The data of the study were collected using a semi-structured interview form consisting of nine items. The data obtained were analyzed through the inductive content analysis method.

\section{Findings}

The findings of the study indicated that for the participants the inclusion of the Human Rights, Citizenship and Democracy course at primary schools is necessary and useful the participants mostly stated that the learning outcomes in the education program are sufficient. The participants are found to employ mostly the traditional teaching and learning methods and techniques in Human Rights, Citizenship and Democracy course. The participants stated that they frequently use the textbook while teaching, and that they also make use of movies, cartoons, news and public service ads on the subjects. In regard to the assessment and measurement in the Human Rights, Citizenship and Democracy courses, it found that the participants mostly employ traditional assessment methods and techniques. They, on the other hand, expressed some difficulties experienced caused by the nature of the course. The participants stated these problems as fewer course hours and abstract nature of the course content. They also added that the linguistic and narration patterns of the stories included in the textbooks are not suitable for the students' developmental levels. In addition, the participants mentioned other problems which are student-sourced, teacher-sourced, in-class practices, physical environment, parents, etc. Finally, the suggestions of the classroom teachers for the solution of these problems experienced in the Human Rights, Citizenship and Democracy course are discussed.

\section{Discussion}

The majority of the participants stated that learning the concepts related to the Human Rights, Citizenship and Democracy course at an early age will make a significant contribution to the individuals. 
They stated that the Human Rights, Citizenship and Democracy course will have an important effect on students' gaining different perspectives and assuming a social role. In line with the findings obtained from the views of the participants, it can be argued that if the Human Rights, Citizenship and Democracy course will continue to be included in the primary school education programs, the course content should be reorganized in a way that is based on practice and learning by doing and living, and that its content should make the students active participants of the learning process.

*Bu çalışma için 09.12.2016 tarihinde Afyon Kocatepe Üniversitesi Bilimsel Yayın ve Etik Kurulundan 2016/137 sayılı etik kurul izni alınmıştır.

**Yazarlar destek için Afyon Kocatepe Üniversitesi'ne ve araştırmaya katılan öğretmenlere teşekkür eder.

***Bu makaleye yazarlar eşit oranda katkı sağlamıştır. 